\title{
Ophrys fusca and Ophrys dyris (Orchidaceae) - constancy of tetraploidy amongst populations in Central Portugal
}

Article

Accepted Version

Abreu, J. A., Hawkins, J. A., Cotrim, H., Fay, M. F., Hildago, O. and Pellicer, J. (2017) Ophrys fusca and Ophrys dyris (Orchidaceae) - constancy of tetraploidy amongst populations in Central Portugal. New Journal of Botany, 7 (2-3). pp. 94100. ISSN 2042-3497 doi:

https://doi.org/10.1080/20423489.2017.1408185 Available at https://centaur.reading.ac.uk/74633/

It is advisable to refer to the publisher's version if you intend to cite from the work. See Guidance on citing.

To link to this article DOI: http://dx.doi.org/10.1080/20423489.2017.1408185

Publisher: Taylor \& Francis

All outputs in CentAUR are protected by Intellectual Property Rights law, including copyright law. Copyright and IPR is retained by the creators or other copyright holders. Terms and conditions for use of this material are defined in the End User Agreement. 


\section{CentAUR}

Central Archive at the University of Reading

Reading's research outputs online 


\title{
Ophrys fusca and O. dyris (Orchidaceae) - constancy of tetraploidy amongst populations in Central Portugal
}

\author{
Ophrys is amongst the best known orchid genera, and is an established system for \\ the study of pollinator-mediated floral evolution. Two species, Ophrys fusca s.l. \\ and Ophrys dyris (= O. omegaifera subsp. dyris) belonging to Ophrys section \\ Pseudophrys are the focus of this study. In the context of an integrative study of \\ morphological and genetic diversity of $O$. fusca and $O$. dyris, genome size (GS) \\ and cytotype diversity were surveyed from Portuguese populations. Flow \\ cytometry methods were used to assess GS, and subsequently determine the \\ ploidy level of 67 specimens, including the species and putative hybrids. \\ Cytotypes were also confirmed based on chromosome counts from the roots of \\ two specimens, one of each species. Constancy of nuclear DNA content $(1 \mathrm{C}=$ \\ $11.19 \mathrm{pg})$ and ploidy level $(2 n=4 x=72,74)$ was documented among all the \\ individuals analysed. Implications are considered, in terms of interpreting the \\ origin and predicting the persistance of putative hybrids.
}

Keywords: central Portugal; chromosome numbers; cytotype; genome size; Ophrys fusca, Ophrys dyris; polyploidy

\section{Introduction}

Ophrys is a distinctive genus supported by morphological and molecular characters, but there is a lack of agreement about the number of species in the genus that has been attributed to interspecific hybridisation and introgression (Devey et al., 2008; Stebbins and Ferlan, 1956). Better documentation of the extent of reproductive isolation between species could inform taxonomy and conservation strategies and contribute to our understanding of pollinator-mediated floral evolution in these charismatic, sexually deceptive orchids. Cytotype characterisation of hybridising species at the population level can be an important component of studies of hybridisation and introgression (interspecific gene exchange, through repeated hybridisation and backcrossing, following Anderson 1949), contributing to the robust interpretation of the co-dominant 
molecular marker data used to measure gene flow (Pellicer et al., 2012). Furthermore, in a hybridisation scenario, isolation barriers due to genetic incompatibilities attributed to the ploidy of the parental taxa may account for low incidence of introgressed individuals. Since homoploid hybrid species may show only weak post-zygotic isolation, ploidy influences the frequency of introgressed individuals. Discriminating between polyploidy and other variables influencing reproductive isolation of hybrids (fertile or partially fertile F1 individuals resulting from the interbreeding between the two species), such as pollinator behaviour, could be important in these plants.

Ophrys dyris Maire and Ophrys fusca Link are one pair of species found in sympatry and offering opportunity for the study of hybridisation in the context of a specialised orchid-pollinator system. These two species are respectively included in the groups omegaifera and fusca of section Pseudophrys Godfery (Orchidaceae) and are closely related (Bernardos et al., 2005; Cotrim et al., 2016; Devey et al., 2008). Despite the different approaches and reported relationships pointed out below, we refer these taxonomic entities as separate species, as our preliminary morphological analysis seem to maintain the segregration between specimens presenting trait expression of the diagnostic characters in the mean values of its description range.

These species are found across the Iberian Peninsula and northern Africa, O. dyris having a narrow and more localised distribution in this region, and $O$. fusca being more common and widespread, with a geographical range that reaches western Asia. Flowers of the latter species are extremely variable in morphology, leading to the segregation of the species into more than ten different species (Delforge, 2002), though other authors have taken a more conservative approach, recognising these two species in the broad sense, with the morphological variants being treated at lower taxonomic levels (Pederson and Faurholdt, 2007). Ophrys dyris is less variable in floral morphology and less abundant throughout 
its distribution range. Both species are listed in protected habitats, as components and bioindicators of habitat 6210 of Directive 92/43/CEE, under which habitats are prioritised when any listed species is numerous.

Ophrys dyris and O. fusca have similar morphological characters, and careful inspection is needed for field identification (Figure 1), particularly as intermediate individuals are known, some of which have been characterised as hybrids using co-dominant molecular marker data (Cotrim et al., 2016).In 1981 the name O. ×brigittae H.Baumann was used to refer to the hybrids between Ophrys dyris and Ophrys fusca. Aside from $O . \times$ brigittae, several other species considered to result from introgression between $O$. dyris and $O$. fusca have been described for Portugal. These are O. algarvensis D.Tyteca, Benito \& M.Walravens, O. vasconica (O.Danesch \& E.Danesch) P.Delforge and O. lenae M.R.Lowe \& D.Tyteca (Lowe and Tyteca, 2012). They were referred to as "paleohybrids" by Lowe and Tyteca (2012), as neither parent is present in the populations, such absence suggesting that hybridization occurred in the past. As far as we know, there are no molecular studies focused on the origin of these putative hybrids which form part of a "partly stabilized hybrid complex" between the omegaifera and fusca groups (Pederson and Faurholdt, 2007). Ophrys dyris itself might be of hybrid origin. Devey et al. (2008) postulated that the plant which represented $O$. dyris in their study was an intersectional hybrid between sections Pseudophrys and Ophrys, and based on ITS and AFLP data it seems likely that the specimen in cause was an F1 hybrid. However, as we are referring to one particular sample, more data are needed to interpret on the potential hybrid origin of the species. 
In Portugal, $O$. fusca and $O$. dyris overlap in at least three limestone regions: in the Aire and Candeeiros Mountains, in Arrábida and in the Algarve. The distribution of putative hybrids and introgressed individuals varies (Abreu et al., in prep.), but it is not known whether post-zygotic isolation due to incompatible parental ploidy could account for these differences. Ophrys fusca is known to exist at diploid $(2 n=2 x=36)$ and tetraploid $(2 n=4 x=72)$ levels (Greilhuber and Ehrendorfer, 1975), whereas tetraploid and pentaploid $(2 n=4 x=90)$ cytotypes of $O$. dyris have been described. Greilhuber and Ehrendorfer (1975) first described tetraploids for Mallorcan specimens of the O. fusca aggregate, but also reported diploid Italian plants. In 2005, D'Emerico et al. reported that Italian $O$. fusca is diploid. In 2007 and 2010, chromosome counts of $2 n=4 x=72,76$ and $2 n=4 x=72$ were reported for $O$. fusca from Arrábida region, Portugal, by GarcíaBarriuso et al. (2010). Cotrim et al. $(2009,2016)$ inferred that specimens from the western Iberian Peninsula with four alleles per individual for some microsatellite loci were tetraploid. Considering O. dyris, following an early report of tetraploid plants (Kullenberg 1961), Bernardos et al. (2003), later cited by Aedo and Herrero (2005) and Amich et al. (2007), reported counts of $2 n=4 x=72$ and $2 n=5 x=90$. A confirmation of $2 n=4 x=72$ was reported by García-Barriuso et al. (2010) for specimens from Montejunto region, Portugal.

This study is part of a wider project describing the genetic and morphometric diversity of O. fusca and O. dyris in central Portugal (Figure 2) and documenting hybridisation and introgression between these species. Here we focus on describing the ploidy of these plants, characterising the accessions to be included in genetic and morphometric surveys with a view to integrative analysis in the future. Our new characterisations will permit robust interpretation of microsatellite data in preparation. Presently, knowledge of ploidy 
levels will clarify whether variants described in the literature are found in the Portuguese populations, may shed light on the hypothesis of hybrid origin for the species $O$. dyris, and on the possible dynamics of the Ophrys fusca-O. dyris populations known in Portugal.

\section{Methods}

\section{Flow cytometry}

As indicated above, nuclear DNA contents were estimated from a subset (67) of the plants that were measured for morphology and collected for DNA analysis in the scope of the broader study. Samples came from the six populations being monitored (Figure 2): O. fusca - 35 from Arruda dos Vinhos (north of Lisbon, AV) and 5 from Casal Facho (Arrábida, CF); O. dyris - 9 from Montejunto (Montejunto mountain, $\mathrm{Mj}$ ) and 10 from Serra de Sto António (Santo António Mountain, SA); samples from populations where both species are present - 3 from Pinheirinhos (Arrábida, Pi) and 5 from Mendiga (Aire and Candeeiros Mountains, Me). Analyses were carried out by flow cytometry using pollinaria instead of leaf tissue, in order to avoid potential misinterpretation of the results given the differential release of nuclei in orchids (Pellicer and Leitch, 2014). To test the performance of pollinaria under different storage conditions, we analysed (i) fresh, (ii) fixed in 3:1 alcohol:acetic acid and (iii) silica-dried pollinaria after collection in the field. Although fresh samples provided good quality results, after several days of storage the quality of the results decayed significantly, so we used silica-dried pollinaria instead, which provided better quality flow histograms and comparable relative fluorescence. Measurements were performed on the pollinaria of 67 plants (Table 1) that had been previously screened with microsatellites. Genome size was also assessed 
using fresh leaves. For the cytotype screening, one to three pollinaria were co-chopped with the selected internal standard [Pisum sativum 'Ctirad' $(2 \mathrm{C}=9.09 \mathrm{pg})$ or Petroselinum crispum 'Curled Moss' $(2 \mathrm{C}=4.45 \mathrm{pg})]$ in a Petri dish containing $1 \mathrm{ml}$ of Ebihara buffer (Ebihara et al., 2005) following the one-step procedure described in Doležel et al. (2007). The nuclei suspension was filtered through a $30 \mu \mathrm{m}$ nylon mesh and stained with $100 \mu \mathrm{l}$ propidium iodide $(1 \mathrm{mg} / \mathrm{ml})$. Samples were kept on ice for 15 min and analysed using a Partec Cyflow SL3 flow cytometer fitted with a $100 \mathrm{~mW}$ green solid state laser (Cobolt Samba). For each run, 3,000 particles were analysed. Measurements from leaves followed the same procedures, with three replicates run for each of the accessions and analysing 5,000 particles per run.

\section{Chromosome counts}

Knowing that all the plants have approximate values for genome size, we chose reference samples from all the populations to assess ploidy level and chromosome numbers. To count the number of chromosomes, root tips of those plants, with genome sizes previously assessed (seven plants from all the populations sampled: two from $\mathrm{Pi}$, one from $\mathrm{AV}$, one from $\mathrm{CF}$, one from $\mathrm{Me}$, one from $\mathrm{Mj}$ and one from $\mathrm{SA}$ ) and collected from the field were used. To promote active root growth, plants had been re-potted one week before pre-treatment with colchicine. After roots were harvested, c. 10-15 mm root tips were cut and placed into a tube of cold distilled water. Samples were then placed into a $0.05 \%$ colchicine $(\mathrm{w} / \mathrm{v})$ solution and placed at $21^{\circ} \mathrm{C}$ for three hours, from where they were transferred to a freshly prepared fixative of 3:1 ethanol:acetic acid. After 48 hours at $4^{\circ} \mathrm{C}$, they were moved to Eppendorf tubes in $70 \%$ ethanol. Roots were then washed in distilled water for 5-10 mins using a shaker at room temperature, and transferred to $1 \mathrm{M}$ hydrochloric acid $(\mathrm{HCl})$ at $60^{\circ} \mathrm{C}$ to be hydrolysed for 5-6 min. For the following staining phase, we used Schiff's reagent for $20 \mathrm{~min}$, and subsequently used 
acetic orcein for a further 20 mins. The root tips were excised with a razor blade under a stereo microscope and mounted on a microscope slide in one drop of $2 \%$ aceto-orcein to be squashed. Plates were then observed on a Zeiss Axioplan Imaging microscope and the metaphase plates photographed with a digital camera (SPOT RT; Diagnostic Inc.). Images were edited with the software ProgRes Capture Pro v2.9.1 (Jenoptik Optical Systems GmbH, Jena, Germany).

\section{Results and discussion}

\section{The use of alternative tissues to estimate GS and infer ploidies in Ophrys}

In recent times, flow cytometry has become the preferred method to estimate nuclear DNA contents in plants, not only because it is fast, reproducible and enables analysis of thousands of particles, but also because it only requires small amounts of tissue (Doležel et al., 2007). Nonetheless, this is not always straightforward, and several taxonomic groups pose challenges due to either the presence of cytosolic compounds or unbalanced numbers of nuclei in $\mathrm{G}_{1}$-phase of mitosis, which may lead to misinterpretation of the resulting flow histograms (Trávníček et al., 2015). Orchids are sometimes challenging due to frequent rounds of endoreplication (including partial endoreplication), which might be tissue-specific, hence efforts have focused in searching for alternatives in order to overcome this problem (e.g. Pellicer and Leitch, 2014; Trávníček et al., 2015). In our study, although Ophrys does not seem to represent a major challenge in this respect, we investigated the use of pollinaria for estimating nuclear DNA contents and allocating DNA-ploidies instead of leaves. We found that the results obtained not only were highly similar (Tables 1 and 2), but the number of particles released were always higher when using pollinaria [e.g. out of 5,000 particles 
(including debris): leaf (337 nuclei), pollinarium (780 nuclei)], thus making our inferences more robust. In addition, since fresh and silica-dried pollinaria resulted in similar relative fluorescences [e.g. ratio standard-sample 1.235(dried)-1.261(fresh)], we also overcome efficiently one of the limitations of flow cytometry, i.e. the need for fresh leaves for high-quality estimations. As reported in Trávníček et al. (2015), pollinaria did not show multiple rounds of endopolyploidy, with most samples only displaying $\mathrm{G}_{1}$ peaks (= 1C-value peak, since these are haploid cells). By contrast, our tests on leaves showed higher levels of endopolyploidy with $2 \mathrm{C}, 4 \mathrm{C}$ and $8 \mathrm{C}$ peaks, with $4 \mathrm{C}$ peaks $\left(\mathrm{G}_{2}\right)$ nuclei more than three times more abundant than $2 \mathrm{C}$ peaks $\left(\mathrm{G}_{1}\right)($ i.e. $300 / 2 \mathrm{C} v$. 1045/4C, Fig. 3).

\section{Tetraploid cytotypes in Ophrys fusca and O. dyris across central Portugal}

Chromosome counts for the two plants from different populations (CF and Pi) and different species, O. fusca (CF02) and O.dyris (Pi15), revealed the same ploidy levels, with chromosome numbers of $2 n=4 x=72,74$, respectively (Fig. 4). Since genome size from pollinaria and from leaves revealed approximately the same nuclear DNA content for all plants (average $1 \mathrm{C}$-value $=11.19 \mathrm{pg}$ ), including typical $O$. fusca and $O$. dyris, specimens with intermediate morphotypes and putative hybrids following molecular analysis (data not shown), we inferred a tetraploid cytotype across central Portugal for the species $O$. fusca and $O$. dyris (Table1), and their putative hybrids (Table1). The difference between the chromosome numbers $(2 n=72,74)$ could be due to aneuploidy events (as identified previously in Ophrys by Greilhuber and Ehrendorfer, 1975), although chromosome breakage during preparation cannot be discounted.

Within species of section Pseudophrys, García-Barriuso et al. (2010) observed a restricted geographic distribution of tetraploids, and interpreted their findings as suggestive of a young polyploid complex sensu Stebbins (1971). Our results provide 
support the view that polyploidy may have played an important role in shaping the evolutionary diversification of section Pseudophrys in the Iberian Peninsula (Amich et al., 2007; García-Barriuso et al., 2010), and that this area is a hotspot of polyploidisation in the section (García-Barriuso et al., 2010). It is notable that the remarkable cytotype consistency amongst the plants analysed here contrasts with the diversity of phenotypes and different genetic groups found (Abreu et al., in prep.). It is also relevant to any discussion of possible fate of hybrids between $O$. fusca and $O$. dyris. Hybridisation in the case of species of the same ploidy could have a range of outcomes, including the establishment of a hybrid swarm, the transfer of traits through introgressive hybridisation, and the origin of new homoploid hybrid species (Yakimowski and Reiseberg, 2014), as already referred as a likely evolutionary mode in Ophrys by Paulus in 1990. Since Stebbins and Ferlan (1956) reported solitary or few fully fertile F1 hybrid individuals in (another pair of) sympatric Ophrys populations but no hybrid swarms, the view has been that the breakdown of species-specific pollinator relationships in Ophrys hybrids would mediate against the establishment of complex hybrid populations. The fact that both species studied here have the same ploidy levels suggests that cytological isolation is not acting as a post-zygotic barrier, at least in this case, and a homoploid hybrid speciation process might be in the beginning. Future dissection of the hybridising populations to identify the frequency of F1, F2 and other hybrid progeny can be interpreted in this light.

\section{The origin of Ophrys dyris}

In 2008, when studying phylogenetic relations between several species of Ophrys, Devey et al. (2008) suggested that either the particular accession used in their analysis was of hybrid origin or the species itself could be of hybrid origin. If the later 
hypothesis holds true, the likely parents would be from sections Pseudophrys and Ophrys (fuciflora aggregate), based on the phylogenetic results obtained by the authors.

Despite being impossible to confirm the identification of such specimen (Bateman, com. pers.) and the uncertainty of this conclusion, as assumed by the authors, our current molecular dataset under analysis supports the idea of a hybrid origin for $O$. dyris. To clarify this idea, plastidial genes were analised in the scope of this study (data not publ.), which seem to indicate $O$. lutea (section Ophrys) as one of the parents. In addition, Cotrim et al. (2016), supported by plastid haplotypes, reported introgressed individuals and hybridising populations between fusca-lutea, bearing out the tight relationship between these species previously pointed out by Soliva et al. (2001). The different hypotheses illustrate different scenarios of breakage of reproductive barriers: the hybrid would be either the outcome of an intersectional cross or a plant with both parents from the same section. As the strength of reproductive isolation mechanisms (mainly postzygotic in sexual deceptive orchids) does not seem to be related with genetic distance or species divergence (Scopece, 2007), both scenarios would be equally plausible. In the light of previous counts and the results presented here, in either case the outcoming hybrid would be tetraploid with a diploid and a tetraploid parent. Such crosses are known to result from fusion of an unreduced $2 n$ gamete from the diploid parent and a normally reduced $2 n$ gamete from the tetraploid parent (Carroll and Borrill, 1965; VanSanten et al., 1991; Petit, 1999). Unreduced gametes are the result of abnormal meiotic division and, despite ease of production in controlled experiments, their frequency in natural populations is still largely unknown. The viability of the resulting hybrid would have been influenced by paternal:maternal ratios, the direction of the cross and by endosperm development (Burton and Husband, 2000; van Santen et al., 2001; Sabara et al., 2013). Maintainance is likely to be 
grounded on competitive ability, higher fecundity, selfing and habitat segregation between cytotypes, as documented by Rodriguez (1996) and cited by Petit (1999). As theorised by the latter author, the establishment of a species such as $O$. dyris might reflect the maintainance of viable populations for successive generations, or the rapid colonisation of new areas. Pre-zygotic isolating mechanisms, such as pollinatormediated isolation, are of major importance for the establishment of such species (Petit 1999). The constancy of cytotypes, recurrent hybridisation events and gene flow between $O$. dyris and $O$. fusca suggest that isolation - at least from one of the putative parents - is not complete. To achieve a more comprehensive understanding of the evolution of this group including clarifying the origin of $O$. dyris, further genetic analyses are being conducted..

\section{References}

Aedo, C. \& Herreo, A., eds. 2005. Orchidaceae, in Castroviejo, S., ed. Flora Iberica. Plantas vasculares de la Peninsula Ibérica e Islas Baleares (Vol. XXI. Smilacaceae-Orchidaceae). Madrid: Real Jardín Botánico.

Amich, F., García-Barriuso, M. \& Bernardos, S. 2007. Polyploidy and speciation in the orchid flora of the Iberian Peninsula. Botanica Helvetica, 117: 143-157.

Anderson, E. 1949. Introgressive hybridisation. New York: John Wiley \& Sons, Inc.

Bernardos, S., Amich, F. \& Gallego, F. 2003. Karyological and taxonomic notes on Ophrys L. (Orchidoideae, Orchidaceae) from the Iberian Peninsula. Botanical Journal of the Linnean Society, 142: 395-406.

Bernardos, S., Crespi, A., Del Rey, F. \& Amich, F. 2005. The section Pseudophrys (Ophrys, Orchidaceae) in the Iberian Peninsula: a morphometric and molecular analysis. Botanical Journal of the Linnean Society, 148(3): 359-375.

Burton, T. L. \& Husband, B. C. 2000. Fitness differences among diploids, tetraploids, and their triploid progeny in Chamerion angustifolium: mechanisms of inviability and implications for polyploid evolution. Evolution, 54(4): 11821191.

Carroll, C. P. \& Borrill, M. 1965. Tetraploid hybrids from crosses between diploid and tetraploid Dactylis and their significance. Genetica, 36(1): 65-82.

Cotrim, H. C., Monteiro, F., Sousa, E., Pinto, M. J. \& Fay, M. F. 2016. Marked hybridization and introgression in Ophrys sect. Pseudophrys in the western Iberian Peninsula. American Journal of Botany, 103(4): 677-691.

Cotrim, H. C., Monteiro, F., Sousa, E. S., Fay, M. F., Chase, M. W. \& Pais, M. S. 2009. Isolation and characterization of novel polymorphic nuclear microsatellite markers from Ophrys fusca (Orchidaceae) and cross-species amplification. [Technical note]. Conservation Genetics, 10(3): 739-742. 
D'Emerico, S., Pignone, D., Bartolo, G., Pulvirenti, S., Terrasi, C., Stuto, S. \& Scrugli, A. 2005. Karyomorphology, heterochromatin patterns and evolution in the genus Ophrys (Orchids). Botanical Journal of the Linnean Society, 148: 87-99.

Delforge, P. ed. 2002. Guía de las Orquideas de España y Europa, Norte de Africa y Próximo Oriente. Barcelona: Lynx Editions.

Devey, D. S., Bateman, R. M., Fay, M. F. \& Hawkins, J. A. 2008. Friends or Relatives? Phylogenetics and species delimitation in the controversial European orchid genus Ophrys. Annals of Botany, 101(3): 1-18.

Doležel, J., Greilhuber, J. \& Suda, J. 2007. Estimation of nuclear DNA content in plants using flow cytometry. [10.1038/nprot.2007.310]. Nature Protocols, 2(9): 22332244.

Ebihara, A., Ishikawa, H., Matsumoto, S., Lin, S.-J., Iwatsuki, K., Takamiya, M., Watano, Y. \& Ito, M. 2005. Nuclear DNA, chloroplast DNA, and ploidy analysis clarified biological complexity of the Vandenboschia radicans complex (Hymenophyllaceae) in Japan and adjacent areas. American Journal of Botany, 92(9): 1535-1547.

García-Barriuso, M., Bernardos, S. \& Amich, F. 2010. Chromosomal evolution in Mediterranean species of Ophrys sect. Pseudophrys (Orchidaceae): an analysis of karyotypes and polyploidy. Taxon, 59(2): 525-537.

Greilhuber, J. \& Ehrendorfer, F. 1975. Chromosome numbers and evolution in Ophrys (Orchidaceae). Plant Systematics and Evolution, 124(2): 125-138.

Kullenberg, B. 1961. Studies in Ophrys pollination. Zoologiska Bidrag från Uppsala, 34: 1-340.

Lowe, M. R. \& Tyteca, D. 2012. Two new Ophrys species from Portugal. Journal Europaischer Orchideen : Mitteilungsblatt des AHO Baden-Württemberg, 44(1): 207-229.

Paulus, H. F. \& Gack, C. 1990. Pollinators as prepollinating isolation factors: evolution and speciation in Ophrys pollination (Orchidaceae). Israel Journal of Botany, 39(1-2): 43-79.

Pederson, H. A. \& Faurholdt, N. ed. 2007. Ophrys. The Bee Orchids of Europe. Kew: Kew Publishing.

Pellicer, J., Clermont, S., Houston, L., Rich, T.C.G. \& Fay, M.F. 2012. Cytotype diversity in the Sorbus complex (Rosaceae) in Britain: sorting out the puzzle. Annals of Botany, 110(6): 1185-1193.

Pellicer, J. \& Leitch, I. J. 2014. The application of flow cytometry for estimating genome size and ploidy level in plants. In P. Besse, ed. Methods in Molecular Biology. New York: Springer, 279-307.

Pridgeon, A. M., Cribb, P. J., Chase, M. W. \& Rasmussen, F. N. 2001. Orchidoideae (Part one). In A. M. Pridgeon, P. J. Cribb, M. W. Chase \& F. N. Rasmussen, eds. Genera Orchidacearum (Second ed., Vol. 2). Oxford: Oxford University Press.

Petit, C., Bretagnolle, F. \& Felber, F. 1999. Evolutionary consequences of diploidpolyploid hybrid zones in wild species. Trends in Ecology and Evolution, 14 (8): 306-311.

Rodriguez, D. J. 1996. A model for the establishment of polyploidy in plants. The American Naturalist, 137(1): 43-46.

Sabara, H. A., Kron, P. \& Husband, B. C. Cytotype coexistence leads to triploid hybrid production in a diploid-tetraploid contact zone of Chamerion angustifolium (Onagraceae). American Journal of Botany, 100(5): 962-970. 
Scopece, G., Musacchio, A., Widmer, A. \& Cozzolino, S. 2007. Patterns of reproductive isolation in Mediterranean deceptive orchids. Evolution, 61(11): 2623-2642.

Soliva, M., Kocyan, A. \& Widmer, A. 2001. Molecular phylogenetics of the sexually deceptive orchid genus Ophrys (Orchidaceae) based on nuclear and chloroplast DNA sequences. Molecular Phylogenetics and Evolution, 20(1): 78-88.

Stebbins, G. L. \& Ferlan, L. 1956. Population variability, hybridization and introgression in some species of Ophrys. Evolution, 10: 32-46.

Stebbins, G. L. 1971. Chromosomal evolution in higher plants. London: Edward Arnold Ltd.

Trávníček, P., Ponert, J., Urfus, T., Jersáková, J., Vrána, J., Hřibová, E., Doležel, J. \& Suda, J. 2015. Challenges of flow-cytometric estimation of nuclear genome size in orchids, a plant group with both whole-genome and progressively partial endoreplication. Cytometry Part A, 87(10): 958-966.

Van Santen, E., Hugessen, P. M. \& Casler, M. D. 1991. Identification and frequency of tetraploid progeny from $2 x-4 x$ and $4 x-2 x$ crosses in Dactylis. Genome, 34(2): 273-278.

Yakimowski, S. B. \& Rieseberg, L. H. 2014. The role of homoploid hybridization in evolution: a century of studies synthesizing genetics and ecology. American Journal of Botany, 101(8): 1247-1258. 
Table captions:

Table 1: Nuclear DNA contents from all the plants assessed, from pollinaria (67).

\begin{tabular}{|c|c|c|c|c|}
\hline Plant & $\begin{array}{l}\text { Fluorescence Ratio } \\
\text { (Sample/Standard) }\end{array}$ & $\begin{array}{l}\text { Relative nuclear } \\
\text { DNA content }\end{array}$ & DNA Ploidy & $\begin{array}{l}\text { Internal } \\
\text { standard }\end{array}$ \\
\hline AV02 & 2.429 & 10.9305 & $4 \mathrm{x}$ & Petroselinum \\
\hline AV03 & 2.518 & 11.331 & $4 \mathrm{x}$ & Petroselinum \\
\hline AV04 & FAIL & & & \\
\hline AV05 & 2.398 & 10.791 & $4 \mathrm{x}$ & Petroselinum \\
\hline AV06 & 2.586 & 11.637 & $4 \mathrm{x}$ & Petroselinum \\
\hline AV07 & 2.488 & 11.196 & $4 \mathrm{x}$ & Petroselinum \\
\hline AV08 & 2.514 & 11.313 & $4 \mathrm{x}$ & Petroselinum \\
\hline AV09 & 2.598 & 11.691 & $4 \mathrm{x}$ & Petroselinum \\
\hline AV10 & 2.411 & 10.8495 & $4 \mathrm{x}$ & Petroselinum \\
\hline AV11 & 2.554 & 11.493 & $4 \mathrm{x}$ & Petroselinum \\
\hline AV12 & 2.521 & 11.3445 & $4 \mathrm{x}$ & Petroselinum \\
\hline AV13 & 2.594 & 11.673 & $4 \mathrm{x}$ & Petroselinum \\
\hline AV14 & 2.649 & 11.9205 & $4 \mathrm{x}$ & Petroselinum \\
\hline AV15 & 1.249 & 11.35341 & $4 \mathrm{x}$ & Pisum \\
\hline AV16 & 2.561 & 11.5245 & $4 \mathrm{x}$ & Petroselinum \\
\hline AV17 & 2.524 & 11.358 & $4 \mathrm{x}$ & Petroselinum \\
\hline AV18 & 2.264 & 10.188 & $4 \mathrm{x}$ & Petroselinum \\
\hline AV19 & 2.604 & 11.718 & $4 \mathrm{x}$ & Petroselinum \\
\hline AV20 & 1.224 & 11.12616 & $4 \mathrm{x}$ & Pisum \\
\hline AV22 & 2.531 & 11.3895 & $4 \mathrm{x}$ & Petroselinum \\
\hline AV24 & 2.549 & 11.4705 & $4 \mathrm{x}$ & Petroselinum \\
\hline AV25 & 2.578 & 11.601 & $4 \mathrm{x}$ & Petroselinum \\
\hline AV26 & 2.567 & 11.5515 & $4 \mathrm{x}$ & Petroselinum \\
\hline AV27 & 2.63 & 11.835 & $4 \mathrm{x}$ & Petroselinum \\
\hline AV28 & 2.549 & 11.4705 & $4 \mathrm{x}$ & Petroselinum \\
\hline AV29 & 2.547 & 11.4615 & $4 \mathrm{x}$ & Petroselinum \\
\hline AV30 & 2.53 & 11.385 & $4 \mathrm{x}$ & Petroselinum \\
\hline AV31 & 2.6 & 11.7 & $4 \mathrm{x}$ & Petroselinum \\
\hline AV32 & 2.452 & 11.034 & $4 \mathrm{x}$ & Petroselinum \\
\hline AV33 & 2.61 & 11.745 & $4 \mathrm{x}$ & Petroselinum \\
\hline AV34 & 2.66 & 11.97 & $4 \mathrm{x}$ & Petroselinum \\
\hline AV35 & 2.637 & 11.8665 & $4 \mathrm{x}$ & Petroselinum \\
\hline AV36 & 2.587 & 11.6415 & $4 \mathrm{x}$ & Petroselinum \\
\hline AV37 & 2.591 & 11.6595 & $4 \mathrm{x}$ & Petroselinum \\
\hline AV38 & 2.629 & 11.8305 & $4 \mathrm{x}$ & Petroselinum \\
\hline $\mathrm{CF} 02$ & 2.565 & 11.5425 & $4 \mathrm{x}$ & Petroselinum \\
\hline CF37 & 2.574 & 11.583 & $4 \mathrm{x}$ & Petroselinum \\
\hline $\mathrm{CF} 42$ & 1.244 & 11.30796 & $4 \mathrm{x}$ & Pisum \\
\hline CF43 & 2.567 & 11.5515 & $4 \mathrm{x}$ & Petroselinum \\
\hline CF58 & 2.541 & 11.4345 & $4 \mathrm{x}$ & Petroselinum \\
\hline
\end{tabular}




\begin{tabular}{ccccc} 
Me68 & 2.649 & 11.9205 & $4 \mathrm{x}$ & Petroselinum \\
\hline Me69 & 2.617 & 11.7765 & $4 \mathrm{x}$ & Petroselinum \\
\hline Me70 & 1.245 & 11.31705 & $4 \mathrm{x}$ & Pisum \\
\hline Me71 & 2.658 & 11.961 & $4 \mathrm{x}$ & Petroselinum \\
\hline Me72 & 2.625 & 11.8125 & $4 \mathrm{x}$ & Petroselinum \\
\hline Mj02 & FAIL & & & \\
\hline Mj10 & 2.541 & 11.4345 & $4 \mathrm{x}$ & Petroselinum \\
\hline Mj19 & 2.632 & 11.844 & $4 \mathrm{x}$ & Petroselinum \\
\hline Mj28 & 2.591 & 11.6595 & $4 \mathrm{x}$ & Petroselinum \\
\hline Mj31 & 1.194 & 10.85346 & $4 \mathrm{x}$ & Pisum \\
\hline Mj54 & FAIL & & & \\
\hline Mj56 & 2.521 & 11.3445 & $4 \mathrm{x}$ & Petroselinum \\
\hline Mj60 & 2.554 & 11.493 & $4 \mathrm{x}$ & Petroselinum \\
\hline Mj61 & 1.167 & 10.60803 & $4 \mathrm{x}$ & Pisum \\
\hline SA04 & 2.542 & 11.439 & $4 \mathrm{x}$ & Petroselinum \\
\hline SA05 & 2.564 & 11.538 & $4 \mathrm{x}$ & Petroselinum \\
\hline SA06 & 1.254 & 11.39886 & $4 \mathrm{x}$ & Pisum \\
\hline SA07 & 1.249 & 11.35341 & $4 \mathrm{x}$ & Pisum \\
\hline SA08 & 2.484 & 11.178 & $4 \mathrm{x}$ & Petroselinum \\
\hline SA12 & 1.236 & 11.23524 & $4 \mathrm{x}$ & Pisum \\
\hline SA13 & 1.285 & 11.68065 & $4 \mathrm{x}$ & Pisum \\
\hline SA21 & 2.622 & 11.799 & $4 \mathrm{x}$ & Petroselinum \\
\hline SA22 & 2.578 & 11.601 & $4 \mathrm{x}$ & Petroselinum \\
\hline SA23 & 2.653 & 11.9385 & $4 \mathrm{x}$ & Petroselinum \\
\hline Pi15 & 1.231 & 11.18979 & $4 \mathrm{x}$ & Pisum \\
\hline Pi80 & 1.289 & 11.71701 & $4 \mathrm{x}$ & Pisum \\
\hline Pi87 & 1.239 & 11.26251 & & Pisum \\
\hline & & & \\
\hline
\end{tabular}

Table 2. Summary of the nuclear DNA contents from flow cytometry using silica-dried pollinaria and fresh leaves of Ophrys fusca and O. dyris. Chromosome numbers for each individual are provided.

Pollinaria [1C-value (S.D.)

CF02 (O. fusca)

Pi15 (O. dyris)
Leaves

[2C-value (S.D.)]
Chromosome number (2n)

$\begin{array}{ccc}\text { [1C-value (S.D.) }] & {[\text { C-value (S.D.) }]} & \text { number }(2 \\ 11.125 \mathrm{pg} & 21.716 \mathrm{pg} & 72\end{array}$

$11.247 \mathrm{pg} \quad 22.120 \mathrm{pg}$
74 
Figure 1. Ophrys fusca Link subsp. fusca (A) and Ophrys dyris Maire (= O. omegaifera H.Fleischm. subsp. dyris (Maire) Del Prete) (B)
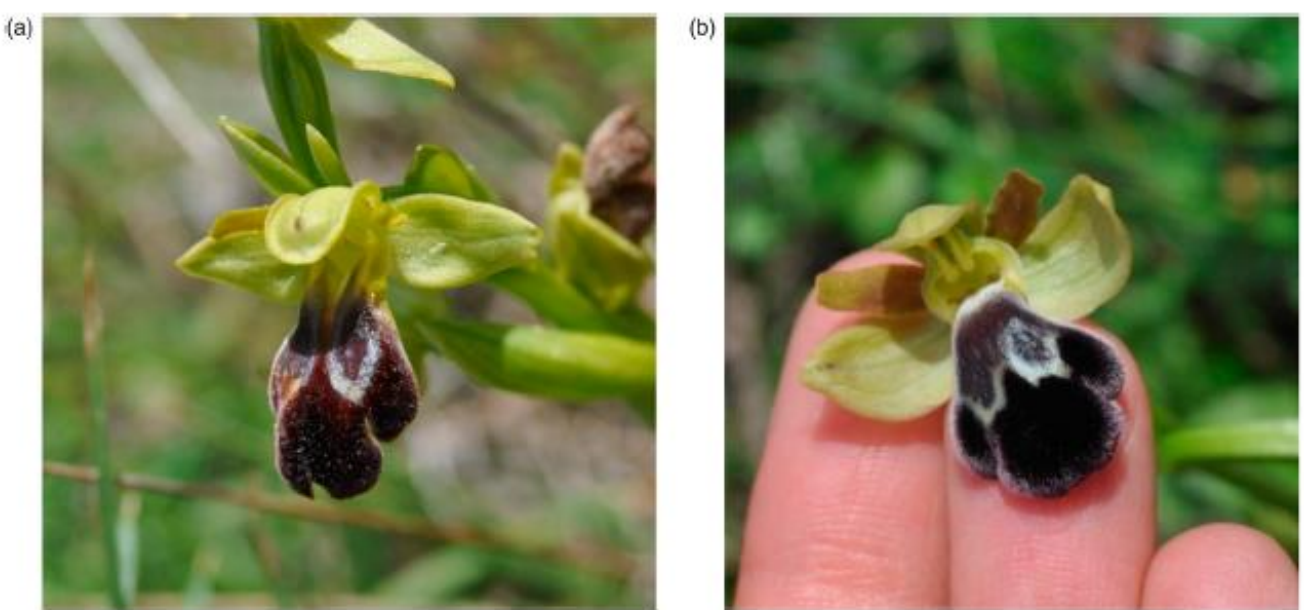
Figure 2. Distribution map of populations sampled in central Portugal. 1. Arruda dos Vinhos (AV); 2. Casal Facho (CF); 3. Montejunto (Mj); 4. Serra de Sto António (SA);

5. Pinheirinhos (Pi); 6. Mendiga (Me)

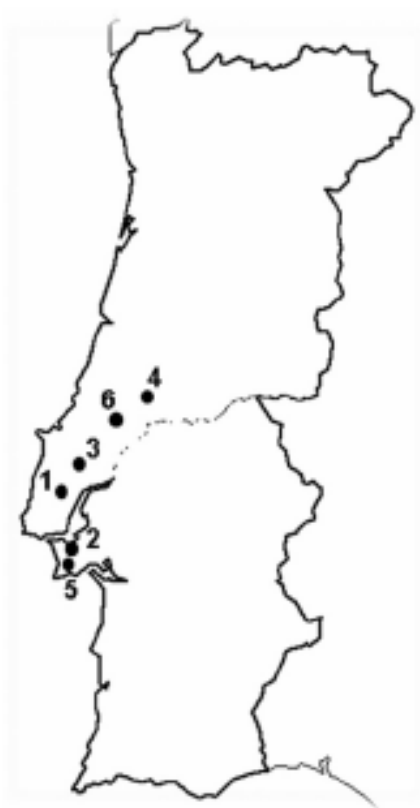

Figure 2 Distribution map of populations sampled in central Portugal. 1. Arruda dos Vinhos (AV); 2. Casal Facho (CF); 3. Montejunto (Mj); 4. Serra de Sto António (SA); 5. Pinheirinhos (Pi); 6. Mendiga (Me). 
Figure 3. Representative fluorescence histograms in Ophrys (* $=2 \mathrm{C}$ and $4 \mathrm{C}$ peaks of the internal standard used (Pisum sativum 'Ctirad'). A. Ophrys dyris leaf analysis (2C $21.99 \mathrm{pg})$. Note that an additional histogram run on logarithmic scale is shown for illustrating the impact of endoreplication (2C, 4C and $8 \mathrm{C}$ peaks displayed). B. Ophrys dyris pollinarium analysis $(1 \mathrm{C} \sim 11.17 \mathrm{pg})$

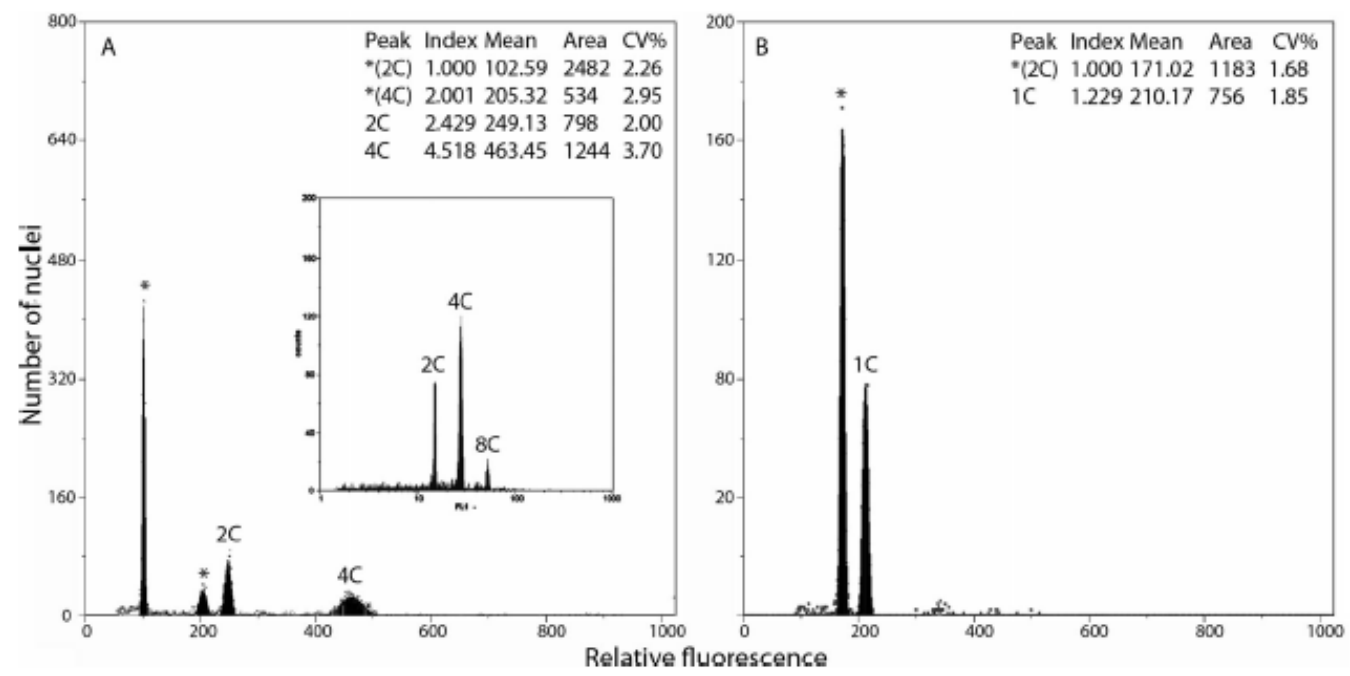


Figure 4. Metaphase cells from root-tips of Ophrys, observed on a Zeiss Axioplan Imaging microscope. A. Ophrys fusca (CF02) $2 n=72$, B. Ophrys dyris (Pi15) $2 n=74$. Scale bar $=10 \mu \mathrm{m}$.
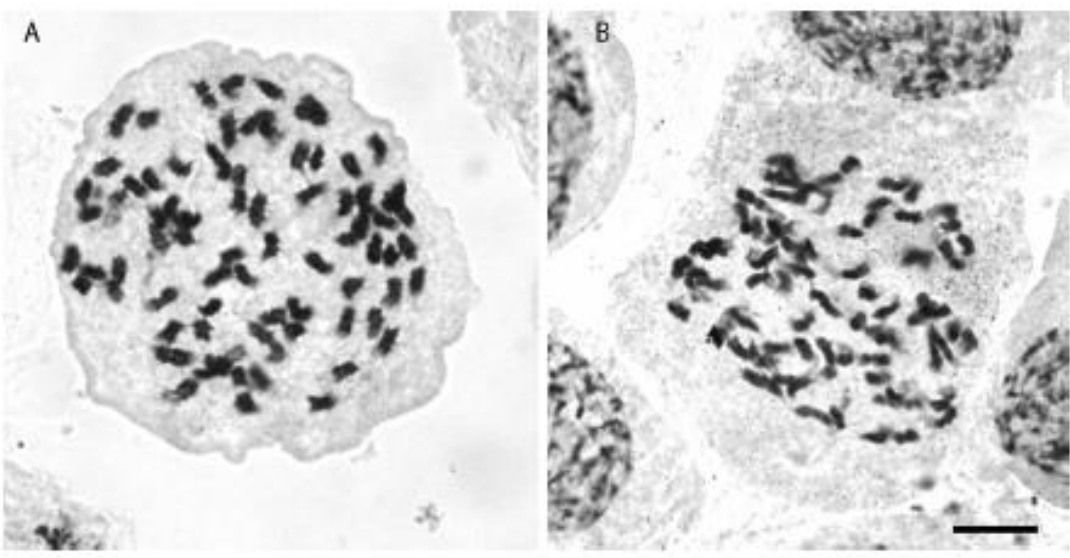